\title{
Leaf development in Xylopia aromatica (Lam) Mart. (Annonaceae): Implications for palatability to Stenoma scitiorella Walker 1864 (Lepidoptera: Elachistidae)
}

\author{
Varanda, EM., Costa, AA. and Barosela, JR.* \\ Departamento de Biologia, Faculdade de Filosofia, Ciências e Letras de Ribeirão Preto, \\ Universidade de São Paulo - USP, \\ Av. Bandeirantes, 3900, Monte Alegre, CEP 14040-901, Ribeirão Preto, SP, Brazil \\ *e-mail: joserb@ffclrp.usp.br
}

Received November 6, 2006 - Accepted February 1, 2007 - Distributed November 30, 2008

(With 2 figures)

\begin{abstract}
Variations in specific foliar mass and water content, nitrogen, soluble carbohydrates and tannins were studied during the growth and maturation processes of the Xylopia aromatica leaves, to determine the effects of such alterations on the herbivory of Stenoma scitiorella caterpillars. This work was carried out in the physiognomy of the typical cerrado of the Parque Estadual de Vassununga, Gleba Pé-de Gigante, Santa Rita do Passa Quatro, São Paulo State, Brazil. While nutritional quality (water and nitrogen) decreases during expansion and maturation of Xylopia aromatica leaves, the chemical (tannins) and physical (sclerophylly) defenses are raised. In agreement with the observations on herbivory, the results support the hypothesis that the reduction in palatability and increase in chemical defenses of Xylopia aromatica leaves account for the caterpillars' preference for young expanding leaves.
\end{abstract}

Keywords: Stenoma scitiorella, Xylopia aromatica, herbivory, leaf development, cerrado.

\section{Crescimento foliar em Xylopia aromatica (Lam) Mart. (Annonaceae): Implicações sobre a palatabilidade para lagartas de Stenoma scitiorella Walker 1864 (Lepidoptera: Elachistidae)}

\section{Resumo}

Com o objetivo de avaliar os efeitos do crescimento e do amadurecimento de folhas de Xylopia aromatica sob o ataque de lagartas de Stenoma scitiorella, foram estudados a variação da área, massa foliar específica, bem como os teores de água, nitrogênio, hidratos de carbono e taninos durante estes processos. O trabalho foi desenvolvido numa fisionomia de cerrado stricto sensu na Gleba Pé-de-Gigante do Parque Estadual de Vassununga, localizado no município de Santa Rita do Passa Quatro, Estado de São Paulo, Brasil. A expansão e o amadurecimento das folhas de Xylopia aromatica resultaram na redução da qualidade nutricional e no aumento de defesas químicas e físicas. Concordando com as observações realizadas sobre a herbivoria, os resultados permitem supor que a redução na palatabilidade das folhas pode explicar a preferência das lagartas por folhas jovens ainda no início do processo de expansão.

Palavras-chave: Stenoma scitiorella, Xylopia aromatica, herbivoria, desenvolvimento foliar, cerrado.

\section{Introduction}

Studies on leaf production and growth, and their effect on the action of folivores are very important in understanding the dynamics of communities and the relationships between herbivorous insects and their host plants (Morais et al., 1995).

Leaf herbivory is one of the main forms of damage to the plants, and is an important selective factor in the evolution of plants (Marquis and Braker, 1994) by affecting directly its photosynthetic performance.

Although the effects of herbivory on plants can sometimes be neutral or even positive, experimental evidence reveals that herbivory results in the loss of nutrients and photosynthetic capacity, affecting the growth, reproduction and survival of plants (Kaitaniemi et al., 1999).

Experiments with simulated defoliation show that young leaves make a larger contribution to the plant's photosynthetic performance than do the mature ones (Coley and Barone, 1996). Previous studies reveal that in most tropical species, expanding young leaves are more heavily attacked by folivores than the mature leaves (Coley and Kursar, 1996). Coley and Barone (1996) determined that daily damage rates to young leaves were from 5 to 25 times higher than to mature leaves. 
In most terrestrial ecosystems already studied, the fauna of herbivores tends to reach a higher density and diversity whenever there are greater sources of young leaves (Damman, 1987). Preference for young leaves by herbivores is related to palatability and has detrimental effects on leaf damage (Coley and Barone, 1996), because on ripened leaves, it is more difficult for herbivores to extract the nutrients they need from the plant tissues (Aide and Londoño, 1989).

Herbivore preference for young leaves could be related to their higher rates of cellular division and growth and the lack of a secondary lignified cell wall, which makes them softer, facilitating their mastication and digestion (Lowman and Box, 1983).

Indigestible components of the cell walls (lignins, cellulose and hemicellulose) comprise 5 to $70 \%$ of the dry matter of most plants, and cellulose alone may account for 20 to $40 \%$ t (Van-Soest, 1982).

Another aspect that can explain the preference of herbivores for young leaves is their relatively high levels of water and nitrogen, compared to mature leaves (Cates, 1980). Low levels of water can be one of the most damaging factors to nourishment of herbivorous insects; since water dilutes nutrients and increases conversion efficiency, many insects demand larger amounts of water in their food (Scriber and Slansky, 1981).

Relatively lower levels of nitrogen in adult leaves can reduce their attack by folivorous insects, because low nitrogen content in leaves may negatively affect their rate of development and also increase the time during which they are more susceptible to predation and parasitism (Feeny, 1976).

If most of the damage caused by herbivory occurs when the leaf is young and if that damage affects the plants' performance, it is important to understand how young leaves are defended. Young leaves show a variety of characteristics that reduce herbivory damages. Some young leaves are more pubescent, containing larger concentrations of tannins and other secondary metabolites than mature ones (Coley and Aide, 1991).

Several defense mechanisms are selected by plants in response to the selective pressures of herbivores (Coley and Barone, 1996). Therefore, insect host plant specialization depends on physiological or behavioral adaptations to overcome the barriers imposed by plant species against herbivory (Ribeiro and Fernandes, 2000), resulting in narrow host ranges among herbivorous insects. This pattern was already described by Diniz and Morais (1997) for the cerrado's Lepidoptera species since 74\% of them occur on only one host plant family.

Barosela (1999) found that, among the 32 morphospecies of chewing herbivores associated with leaves of Xylopia aromatica, Stenoma scitiorella Walker (Lepidoptera: Elachistidae), caterpillars were the most frequent species. This insect is responsible for more than $90 \%$ of leaf damage, feeding exclusively on young leaves.
The aim of this work was to determine the effect of physical (sclerophylly) and nutritional (water, nitrogen and carbohydrates) characteristics and secondary metabolites (tannins) as defense mechanisms against $S$. scitiorella caterpillars, during the growth and maturation of $X$. aromatica leaves.

\section{Material and Methods}

Studies were carried out in the typical cerrado area of the Gleba Pé-de Gigante, part of the six discontinuous natural vegetation areas that comprise the Parque Estadual de Vassununga, located in Santa Rita do Passa Quatro, São Paulo State, Brazil. The regional climate is tropical with two well-defined seasons: a dry season from May to October and a wet season from November to April (Batalha, 1997).

Xylopia aromatica (Lam.) Mart. (Annonaceae) is an arboreal and very abundant species in the study area (Batalha, op. cit.). It has a maximum average height of $6 \mathrm{~m}$, with a distribution ranging from Central America to Brazil, and is very common in cerrado areas (OliveiraFilho and Ratter, 1995). Preliminary phytochemistry analyses of the leaves from this species revealed the presence of saponins, tannins, alkaloids (Silva et al., 1976) and essential oils (Fournier et al., 1994).

Stenoma scitiorella is a microlepidopteran species, subfamily Stenomatinae. Females lay eggs on $X$. aromatica leaf primordia, and after egg hatching, caterpillars connect the adjacent young leaves with silk threads, and take refuge inside shelter, feeding exclusively on internal leaves. Silk produced by the caterpillars prevents the development of young leaves and promotes their detachment. In that way, the attack of this insect not only affects survival of the leaves used as a food resource, but also affects the adjacent young leaves which are used in the construction of the shelters and in some cases promotes the growth of branches by damaging the apical meristem (Barosela, 1999). S. scitiorella caterpillars are found exclusively on $X$. aromatica leaves (I. R. Diniz, pers. comm.), and is responsible for most of the damage caused by herbivores to this plant (Barosela, op. cit.).

The growth and maturation of $X$. aromatica leaves were observed during the rainy season, from December, 2000 to February, 2001. Thirty plants with a height between 1.5 and $2.0 \mathrm{~m}$ were selected for this study. Petioles of 15 recently emerging leaf primordia from each plant were marked with colored threads. Collections and observations were carried out every two days, until complete expansion of the leaves, and afterwards, observation intervals were longer ( $7,8,5$ and 11 days). On each field trip, the number of leaves damaged by caterpillars was recorded. In addition, four marked leaves per plant were photographed using a digital camera and a scale. Images of the leaves were used for the determination of length, width and area by the SIARCS software, version 3.0, developed by EMBRAPA (Leoni et al., 1997). 
Six samples of marked leaves were randomly collected from all plants for measuring characteristics that could affect their palatability: leaf specific mass and contents of water, nitrogen, soluble carbohydrates and tannins.

Leaf specific mass was measured using five disks of a known area extracted from each collected leaf, which were dehydrated and weighed. Leaf specific mass was used to estimate leaf sclerophylly and calculated by the formula: $\mathrm{MAF}=\mathrm{Ms} / \mathrm{A}$, where MAF = dry mass per foliar area, Ms = drymass $(\mathrm{mg})$ and $\mathrm{A}=$ foliar area.

Other leaves were immediately weighed after collection, and then taken to the laboratory and maintained in a stove at $50{ }^{\circ} \mathrm{C}$ for 48 hours. Water content of the leaves was obtained by the formula: [(Mf. Ms)/Mf].100, where: $\mathrm{Mf}=$ fresh mass and Ms = dry mass. Contents of nitrogen, soluble carbohydrates and tannins were determined by Kjeldahl (Allen et al., 1974), Buysse and Merckx (1993) and Hagerman and Butler (1978) methods, respectively. Each leaf field sample was analyzed three times (laboratory replicates). Statistical evaluation of the data was performed using SigmaStat software.

\section{Results}

Complete $X$. aromatica leaf growth, starting from leaf primordia, took seven days (Figure 1a), and the leaves reached $9.95 \pm 1.77 \mathrm{~cm}$ in length, $3.53 \pm 0.61 \mathrm{~cm}$ in width and an area of $24.52 \pm 7.74 \mathrm{~cm}^{2}(\mathrm{~N}=60)$.

Specific foliar mass increased after complete leaf expansion until the $15^{\text {th }}$ day when it was around $10 \mathrm{mg} . \mathrm{cm}^{-2}$ (Figure 1b).

Many marked X. aromatica leaves $(34.0 \%)$ were damaged in the first two days of expansion. In the third and fourth days of expansion, only $9.09 \%$ of marked leaves were damaged. No additional damage was observed after the fifth day.

In $X$. aromatica, the content of water in young leaves reached approximately $70 \%$, decreasing to $60 \%$ after complete expansion and maturation (Figure 1c).

During growth and maturation, the leaves of $X$. aromatica also underwent alterations in nitrogen and soluble carbohydrate contents. As with water content, the amount of nitrogen was higher in the young leaves than in the mature ones (Figure 2a).

Differently, the concentration of soluble carbohydrates in the leaves of $X$. aromatica reached its maximum after complete expansion. Later, it decreased by the $20^{\text {th }}$ day after complete expansion, and increased again by the $41^{\text {st }}$ day. The lowest carbohydrate content was obtained during expansion, and the highest content for leaves was 41 days after complete expansion (Figure $2 b$ ).

Tannin content increased after complete leaf expansion and reached its maximum value on the $41^{\text {st }}$ day (Figure 2c).

Pearson's correlation coefficient revealed correlations between the variables studied (Table 1). There were negative correlations between water content and SFM,
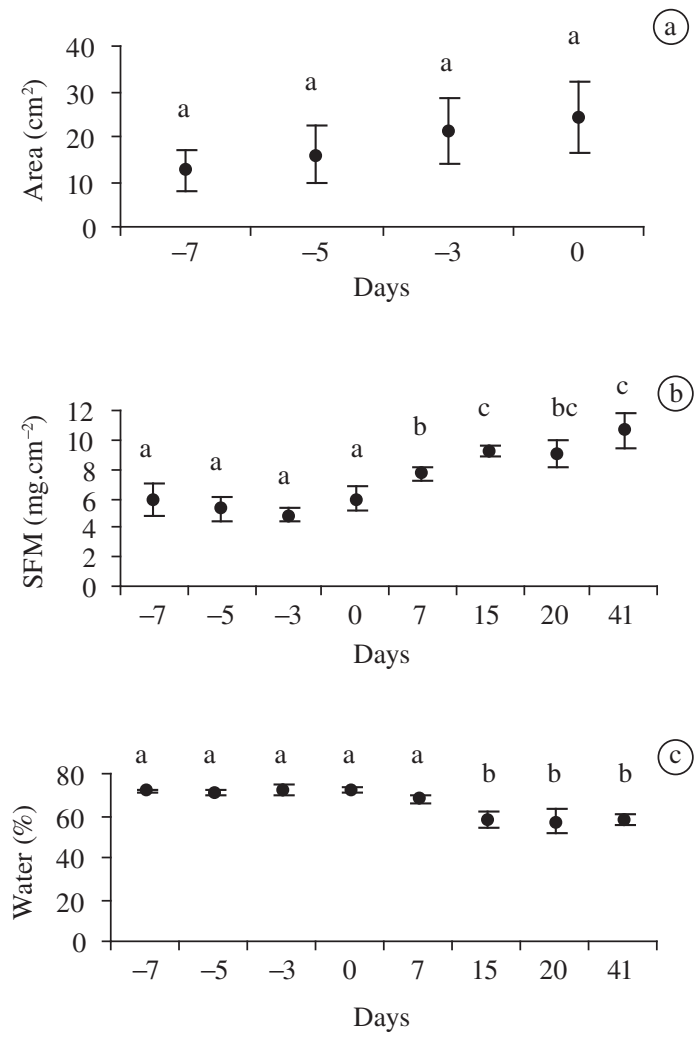

Figure 1. Physical characteristics and water contents of Xylopia aromatica (Annonaceae) leaves in different developmental stages at Gleba Pé-de-Gigante, Parque Estadual de Vassununga. The abscissa is not uniform, and negative and positive values indicate, respectively, days before and after complete leaf expansion. Values are mean and when followed by the same letter are not statistically different $(\mathrm{P}<0.05)$. Vertical bars indicate standard deviation. $\mathrm{SFM}=$ specific foliar mass.

water and tannin contents, and between water and carbohydrate contents. Pearson correlation between nitrogen and SFM, and between nitrogen and tannin contents were also negative. There were positive correlations between water and nitrogen contents and between tannin content and SFM and between tannin and carbohydrate contents.

\section{Discussion}

Differences in leaf specific foliar mass, an indication of the rate of sclerophylly in X. aromatica leaves, were not significant during foliar expansion. However, after the expansion there was an increase in dry matter (Figure 1b). After leaf expansion of X. aromatica, an increase in sclerophylly becomes a mechanical barrier for potential herbivores, mainly those without physiologic mechanisms or symbiotic associations that promote digestion of the lignified wall, e.g. lepidopteran caterpillars (Martin, 1983). 
One common strategy of insects that feed on plant tissues with variable levels of nitrogen is the synchrony of their life cycle and feeding periods with plant phenology phases that show larger sources of nitrogen in tissues (Kursar and Coley, 1991). This explains, in part, why most damage occurs during the first days of $X$. aromatica leaf expansion. However, it is possible that differences in the levels of nitrogen between young and mature leaves do not directly reflect differences in the protein nutritional values of those leaves. Some studies have suggested that nonprotein nitrogenous substances predominate in rapidly maturing plant tissues such as young leaves (Feeny, 1970).

After expansion, the reduction in photosynthetic capacity may have reduced the levels of soluble carbohydrates. As there is no recovery of the photosynthetic capacity, the trend would be continuous reduction in levels of soluble carbohydrates. However, the recorded level by the $41^{\text {st }}$ day after complete expansion, overcame
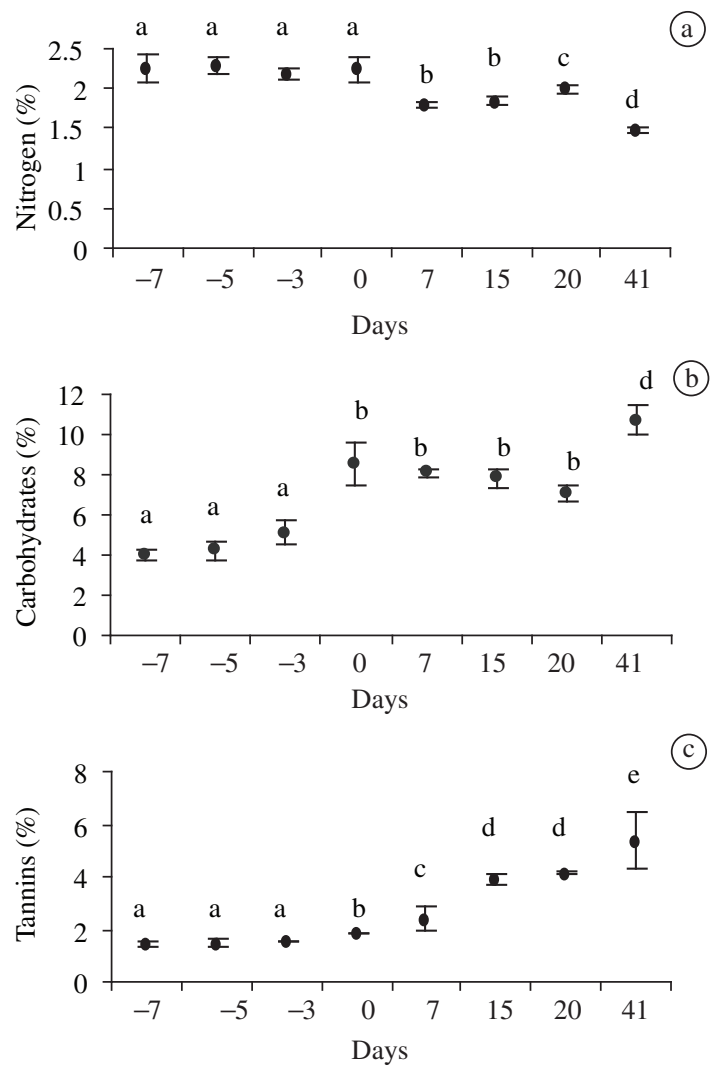

Figure 2. Chemical characteristics of Xylopia aromatica (Annonaceae) leaves in different developmental stages at Gleba Pé-de-Gigante, Parque Estadual de Vassununga. The abscissa is not uniform, and negative and positive values indicate, respectively, days before and after complete leaf expansion. Values are means and when followed by the same letter are not statistically different $(\mathrm{P}<0.05)$. Vertical bars indicate standard deviation. all observed decreased values. It is possible that, after the $20^{\text {th }}$ day of complete expansion, leaves start a process of accumulating photosynthetic products. Even with low productivity, soluble carbohydrates may reach high levels. Accumulation of soluble carbohydrates in the foliar tissues has been explained as a result of nutrient or nitrogen deficiencies (Bhat et al., 1979). Pearson correlation between the levels of nitrogen and soluble carbohydrates was negative and relatively high compared to other analyzed variables (Table 1) and, therefore, allows us to consider this hypothesis.

Nutritionally, soluble carbohydrates constitute the main source of energy for insects, but low levels of soluble carbohydrates in young leaves of $X$. aromatica were not detrimental to $S$. scitiorella caterpillar nourishment. This is probably because some species of phytophagous insects are able to substitute the carbohydrates of their diets with certain amino acids or fats (Parra, 1991). Another explanation is that the low levels of soluble carbohydrates are sufficient to supply the caloric needs of this insect. Studies on nutritional ecology show that despite similar qualitative demands, the concentrations and proportions of nutrients affect herbivorous insect species differently (Parra, op. cit.; Fischer and Fiedler, 2000).

The excess of carbohydrates in mature leaves may lead to a strategy of the activation of synthetic pathways for phenol substances, e.g., tannins, and of the increase in sclerophylly to incorporate the excess carbon in both chemical and physical defenses (Coley et al., 1985). This hypothesis is supported by $X$. aromatica results, since a higher correlation value was obtained for tannins and specific foliar mass (Table 1).

Tannin content in $X$. aromatica leaves increased as leaves matured, so that the highest concentrations of these substances were found in older leaves. Low tannin content recorded during the entire leaf expansion process suggests that, due to the fast growth, young leaves use all the available resources and photosynthesis products in cellular multiplication and differentiation processes, so that during growth, most of the secondary metabolic pathways, including tannin synthesis, show low activity. Increased tannin levels in $X$. aromatica after complete expansion is probably an important protection for mature

Table 1. Pearson's correlation coefficient between physical and chemical variables analyzed in different developmental stages of leaves of Xylopia aromatica (Annonaceae) from Gleba Pé-de-Gigante, Parque Estadual de Vassununga, Santa Rita do Passa Quatro, SP. $(\mathrm{P}<0.05)$. SFM = specific foliar mass

\begin{tabular}{lcccc}
\hline & Water & SFM & Tannins & Nitrogen \\
\hline Water & - & - & - & - \\
SFM & -0.93 & - & - & - \\
Tannins & -0.95 & 0.97 & - & - \\
Nitrogen & 0.75 & -0.86 & -0.85 & - \\
Carbohydrates & -0.58 & 0.77 & 0.76 & -0.85 \\
\hline
\end{tabular}


leaves, since tannins are efficient quantitative defenses not only against herbivores, but also against microorganisms.

Increase in tannin concentration observed during $X$. aromatica leaf maturation, the abundance of this species in the study area (Batalha, 1997), and the fact that this species is a perennial foliar tree corroborate the apparency hypothesis proposed by Feeny (1976). The latter author considered that in apparent and predictable plants and tissues, quantitative defenses are more common.

Finally, the growth process of $X$. aromatica leaves promotes reduction in nutritional quality (water and nitrogen) and increase in the chemical (tannins) and physical (sclerophylly) defenses. Therefore, as leaves mature, they loose characteristics that make them palatable to S. scitiorella caterpillars.

Most of the damage to leaves of $X$. aromatica is caused by $S$. scitiorella caterpillars, and these caterpillars are most abundant during the rainy season, when this plant species has the highest leaf production (Barosela, 1999). The main hypothesis of the evolution of the reproductive behavior of holomethabolous insects suggests that the appropriate choice of place for egg laying is crucial to the survival and development of the larval phase, mainly in view of its reduced mobility (Renwick, 1989). If S. scitiorella eggs are laid on leaves in advanced stage of expansion, caterpillars will be subjected to the unfavorable conditions offered by mature leaves. This way, the greatest damage to leaves in the first days of expansion can reflect female egg laying preference by this microlepidopteran species, in response to the alterations observed in leaves of $X$. aromatica in different developmental stages.

Acknowledgements - The Fundação de Amparo à Pesquisa do Estado de São Paulo (FAPESP) awarded a Master's degree scholarship to the second author. Prof. Dr. Vitor Osmar Becker carried out the identification of Stenoma scitiorella.

\section{References}

AIDE, TM. and LONDONOO, EC., 1989. The effects of rapid leaf expansion on the growth and survivorship of a lepidopteran herbivore. Oikos, vol. 55, no. 1, p. 66-70.

ALLEN, SE., GRIMSHAW, HM., PARKINSON, JA. and QUARMBY, C., 1974. Chemical analysis of ecological materials. Oxford: Blackwell Scientific Publications. 565 p.

BAROSELA, JR., 1999. Herbivoria foliar em Xylopia aromatica (Lam.) Mart. de três fisionomias de cerrado e sua relação com o teor de taninos, valor nutritivo e entomofauna associada. São Carlos, SP: UFSCar. [Master Thesis].

BATALHA, MA., 1997. Análise da vegetação da ARIE Cerrado Pé-de-Gigante (Santa Rita do Passa Quatro, SP). São Paulo, SP: IB-USP. [Master Thesis].

BHAT, KKS., HYE, PH. and BRERETON, AJ., 1979. The possibility of predicting solute uptake and plant growth response from independently measured soil and plant characteristics. VI. The growth and uptake of rape in solutions of constant nitrate concentration. Plant Soil, vol. 53, no. 1-2, p. 137-167.
BUYSSE, J. and MERCKX, R., 1993. An improved colorimetric method to quantify sugar content of plant tissue. J. Exp. Bot., vol. 44, no. 267, p. 1627-1629.

CATES, RG., 1980. Feeding patterns of monophagous, oligophagous and polyphagous insects herbivores: the effect of resource abundance and chemistry plant. Oecologia, vol. 46, no. 1 , p. 22-31

COLEY, PD., BRYANT, J. and CHAPIN, F. 1985. Resource availability and plant antiherbivore defense. Science vol. 230, no. 8 , p. 895-899.

COLEY, PD. and AIDE, TM., 1991. Comparison of herbivory and plant defenses in temperate and tropical broadleafed forests. In PRICE, PW., LEWINSOHN, TM., FERNANDES, GW. and BENSON, WW. (Eds.). Plant-Animal interactions: evolutionary ecology in tropical and temperate regions. New York: John Wiley \& Sons.

COLEY, PD. and BARONE, JA., 1996. Herbivory and plant defenses in tropical forests. Annu. Rev. Ecol. Syst., vol. 27, p. 305-335.

COLEY, PD. and KURSAR, TA., 1996. Anti-herbivore defenses of young tropical forests: physiological constraints and ecological trade-offs. In SMITH, AP., MULKEY, SS. and CHAZDON, RL. (Eds.). Tropical forest plant ecophysiology. London: Chapman and Hall.

DAMMAN, H., 1987. Leaf quality and enemy avoidance by the larvae of a pyralid moth. Ecology, vol. 68, no. 1, p. 88-97.

DINIZ, IR. and MORAIS, HC., 1997. Lepidopteran caterpillar fauna of cerrado host plants. Biodivers. Conserv., vol. 6, p. $817-836$.

FEENY, P., 1970. Seasonal changes in oak leaf tannins and nutrients as a cause of spring feeding by winter moth caterpillar. Ecology, vol. 51, no. 4, p. 565-581.

-, 1976. Plant apparency and chemical defense. Recent Adv. in Phytochem. vol. 10, p. 1-40.

FISCHER, K. and FIEDLER, K., 2000. Response of the cooper butterfly Lycaena tityrus to increased leaf nitrogen in natural food plants: evidence against the nitrogen limitation hypothesis. Oecologia, vol. 124, no. 2, p. 265-271

FOURNIER, G., HADJAKHOONDI, A., CHARLES, B., FOURNIAT, J., LEBOEUF, M. and CAVE, A., 1994. Chemical and biological studies of Xylopia aromatica stem bark and leaf oils. Planta Med., vol. 60, no. 3, p. 283-284.

HAGERMAN, A. and BUTLER, LG., 1978. Protein precipitation method for quantitative determination of tannins. J. Agric. Food Chem., vol. 26, no. 4, p. 809-810.

KAITANIEMI, P., NEUVONEN, S. and NYYSSÖNEN, T., 1999. Effects of cumulative defoliations on growth, reproduction, and insect resistance in mountain birch. Ecology, vol. 80 , no. 2 , p. $524-532$.

KURSAR, TA. and COLEY, PD., 1991. Nitrogen content and expansion rate of young leaves of rain forest species: implication for herbivory. Biotropica, vol. 23, no. 2, p. 141-150.

LEONI, E., JORGE, LAC., VARANDA, EM. and CRESTANA, S., 1997. Medição de área foliar em estudos de herbivoria utilizando processamento de imagens digitais. In Anais do I SIAGRO. São Carlos: EMBRAPA-CNPDIA. p. 327-330. 
LOWMAN, MD. and BOX, JD., 1983. Variation in leaf toughness and phenolic content among five species of Australian rainforest trees. Aust. J. Ecol., vol. 8, no. 1, p. 17-25.

MARQUIS, RJ. and BRAKER, HE., 1994. Plant-herbivore interactions: diversity, specificity, and impact. In MCDALE, LA., BAWA, KS., HESPENHEIDE, HA. and HATSHORN, GS. (Eds.). La Selva - Ecology and Natural History of a Neotropical Rain Forest. Chicago: University of Chicago Press.

MARTIN, MM., 1983. Cellulose digestion in insects. Comp. Biochem. and Physiol., vol. 75, no. 3, p. 313-324.

MORAIS, HC., DINIZ, IR. and BAUMGARTEN, L., 1995. Padrões de produção de folhas e sua utilização por larvas de Lepidoptera em um cerrado de Brasília. Rev. Bras. Bot., vol. 18, no. 2, p. 163-170.

OLIVEIRA-FILHO, AT. and RATTER, JA., 1995. A study of the origin of central brazilian forests by the analysis of plant species distribution patterns. Edinb. J. Bot, vol. 52, no. 2, p. 141-194.
PARRA, JRP., 1991. Consumo e utilização de alimentos por insetos. In PANIZZI, AR. and PARRA, JR. (Eds.). Ecologia nutricional de insetos e suas implicações no manejo de pragas. São Paulo, SP: Editora Manole Ltda/CNPq.

RENWICK, JAA., 1989. Chemical ecology of oviposition in phytophagous insects. Experientia, vol. 45, no. 3, p. 223-228.

RIBEIRO, SP. and FERNANDES, GW., 2000. Interações entre insetos e plantas no cerrado: teoria e hipótese de trabalho. In MARTINS, RP., LEWINSOHN, TM. and BARBEITOS, MS. (Eds.). Ecologia e comportamento de insetos. Série Oecologia Brasiliensis. Rio de Janeiro, RJ: PPGE-UFRJ.

SILVA, JB., SALATINO, A. and PANIZZA, S., 1976. Ensaios fitoquímicos preliminares em espécies do cerrado. Rev. Botanica Univ. S. Paulo, vol. 4, p. 129-132.

SCRIBER, JM. and SLANSKY, F., 1981. The nutritional ecology of immature insects. Annu. Rev. Entomol., vol. 26, p. $183-211$.

VAN-SOEST, PJ., 1982. Nutritional Ecology of the Ruminant. Corvallis: OandB Books Inc. 